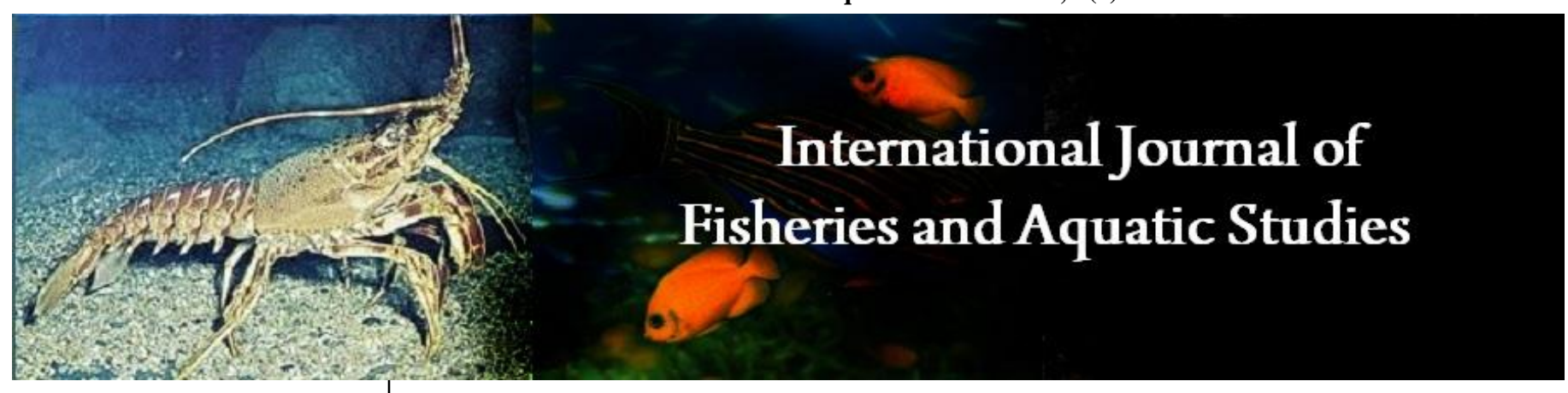

E-ISSN: 2347-5129

P-ISSN: 2394-0506

(ICV-Poland) Impact Value: 5.62

(GIF) Impact Factor: 0.549

IJFAS 2021; 9(2): 195-200

(C) 2021 IJFAS

www.fisheriesjournal.com

Received: 22-01-2021

Accepted: 25-02-2021

Aurobinda Das

Department of Zoology,

Centurion University of

Technology and Management,

Odisha, India

Yashaswi Nayak

Department of Zoology,

Centurion University of

Technology and Management,

Odisha, India

Supriya Dash

Department of Biotechnology,

College of Engineering and

Technology, Odisha, India
Corresponding Author:

Aurobinda Das

Department of Zoology,

Centurion University of

Technology and Management,

Odisha, India

\section{Fish protein hydrolysate production, treatment methods and current potential uses: A review}

\author{
Aurobinda Das, Yashaswi Nayak and Supriya Dash
}

DOI: $\underline{\text { https://doi.org/10.22271/fish.2021.v9.i2c.2452 }}$

\begin{abstract}
About 20 per cent of the live weight of freshwater fish is visceral mass is a rich source of protein, lipids, polyunsaturated fatty acids, soluble vitamins, phospholipids etc having very great source of agro industrial products. Any scientific technique that uses strong squanders coming about because of fish harvesting by recuperating biomolecules like lipids and proteins brings about extra income as well as helps to reduce the dumping issues related therewith. Visceral fish hydrolysate (also known as fish protein hydrolysate; FPH) has drawn the interest of many researchers in recent years due to its great utility in the fields of food, pharmaceuticals, cosmetics and nutrition. The extraction or production of FPH including predefined sequential steps like collection of raw materials, pretreatment (alcohols, heat treatment, press technique coupled with heat treatment), hydrolysis (acidic, alkaline, enzymatic) and recovery of FPH using spray drying, lyophilisation, centrifugation or nanofiltration. The extracted FPH is characterized for molecular mass, protein content, structure of protein, IR, XRD etc to analyse the chemical nature of the FPH. It is widely used as emulsifier, binder, gelling agent, fertilizer, crayoprotectant and dietary additives in various industries. FPH has been used as potential source of microbial growth media for gram positive and negative microbes, nutritional supplement due to higher protein content (60-90\%), and antioxidant, antihypertensive and antimicrobial agent. FPH is also used as nutriceuticals and some of the products are commercially available in various countries including US, Canada, UK. Considering the physicochemical difficulties associated with FPH, its excellent nutritional and functional properties generate possibilities for its usage in both the food and health industries.
\end{abstract}

Keywords: hydrolysates, fish viscera, antioxidant, antihypertensive, hydrolysis, purification

\section{Introduction}

India is the second largest manufacturer of freshwater farmed fish in the world. One of the most used sources of protein for human consumption is fish and aquatic products (New, 2000) [30]. During 2018, India's total fish production amounted to almost 6.24 million metric tones (MMT), which was very close to two-thirds of the total fish produced in the country from both sources of catch and cultivation (Lauria et al., 2018) ${ }^{[25]}$. Continuous increases in fish production, at an annual average rate of $3.2 \%$, and an increase in fish intake per capita from $9.9 \mathrm{~kg}$ in 1960 to $19.2 \mathrm{~kg}$ in 2012 have resulted in to formation larger amounts of organic ravage (Freitas-Júnior et al., 2012) ${ }^{[13]}$. Scales, skin, visceral mass (viscera, air bladder, gonads, and other organs), head, and fins are among the by-products produced during fish processing. About 20 per cent of the live weight of freshwater fish is visceral mass and is a rich source of protein, lipids, polyunsaturated fatty acids, soluble vitamins, phospholipids etc having very great source of agro industrial products. About 91 million tonnes of fish are harvested per year, 29.5 percent of which is turned into fishmeal. Depending on the processing stage and fish species, production results in waste of 20-80 percent. Maybe more than 50 percent of the remaining fish tissue processes waste and is not consumed as food, causing burdensome issues with recycling and environmental concerns (Bhaskar et al., 2011) ${ }^{[5]}$. Any scientific technique that uses strong squanders coming about because of fish harvesting by recuperating biomolecules like lipids and proteins brings about extra income as well as helps to reduce the dumping issues related therewith (Vidotti et al., 2003) ${ }^{[41]}$. Keeping all these things into consideration, scientific studies and research has been carried out to explore innovative and effective innovations that could reduce the burden of environmental challenges. 
In all these studies a kind of protein called visceral fish hydrolysate (also known as fish protein hydrolysate) has drawn the interest of many researchers in recent years due to its great utility in the fields of food, pharmaceuticals, cosmetics and nutrition (Thiansilakul et al., 2007) ${ }^{\text {[37] }}$. Fish visceral hydrolysate is protein obtained from the visceral waste mass of fish including gut, liver, fins and other organs under specific temperature, $\mathrm{pH}$ and enzymatic conditions using pepsin, trypsin, alkalase and chymotrypsin etc (Chalamaiah et al., 2012) ${ }^{[7]}$. Fish protein hydrolysate (FPH) may be liquid or amorphous hygroscopic powder with nearly 81-93 percent protein, 3-8 percent ash, less than 5 percent fat and 1-8 percent humidity. The liquid FPH is a watery combination of hydrolyzed proteins with almost $90 \%$ moisture, which makes it particularly unstable for long-term storage and makes transportation difficult. Therefore dried FPH is preferred over liquid FPH due to greater stability, extended shelf life and ease in transportation. However, the removal of almost 90 percent of water from liquid FPH is the major challenge and quite costly for production of dried FPH (He et al., 2013; Silva et al., 2014) ${ }^{[18,19,35]}$. Table 1 shows the approximate protein content in various waste parts of the fish.

Table 1: Protein content in waste parts of the fish

\begin{tabular}{|c|c|c|}
\hline Sr. No & Fish waste part & Protein \% \\
\hline 1 & Viscera & $9-23$ \\
\hline 2 & Head & $11-13$ \\
\hline 3 & Back bone & $10-15$ \\
\hline 4 & Skin & $8-12$ \\
\hline 5 & Milt & $14-27$ \\
\hline 6 & Cut offs & $12-22$ \\
\hline
\end{tabular}

The FPH is widely used in food, agriculture, pharmaceutical and, biotechnology industry as emulsifier, binder, gelling agent, fertilizer, crayoprotectant and dietary additives (Kristinsson et al., 2000) ${ }^{[23]}$. The objectives of this review is therefore to provide a light on the agro-industrial potential of fish waste as a source, especially viscera, to extract native proteins and hydrolysate and to clarify their manufacturing process, their chemical structure and their functional and bioactive properties.

\section{Extraction (Production) Of Fish Visceral Hydrolysates}

The production of FPH consists of predefined sequential steps by step procedure for separation of fish visceral hydrolysates. The steps include pretreatment, hydrolysis and recovery of FPH (Petrova et al., 2018; Villamil et al., 2017) ${ }^{[33,42]}$. The goal of the development of protein hydrolysates from fish viscera is to solubilize the protein source by chemical or enzymatic methods to boost its biological and nutritional value in order to obtain products of high added value and commercial importance that shape different size peptides. In this section we will discuss the detailed extraction process of FPH.

\subsection{Collection of raw materials and pretreatment}

Fish and fish left-overs may be raw materials for the processing of FPH. Although the production can be influenced by the use of whole fish or just fish by-products. In order to ensure successful recovery of protein fraction, raw materials should be closely analyzed at the technical line. Production process of FPH starts with the collection of raw materials i.e. various fish parts including viscera, scales, fins and carcass etc. The collected fish left overs are cleaned and washed with water to remove the dirt, debris and other unwanted parts from the surface of tissues and then these are chopped in to smaller pieces (mincing) so as to facilitate the effective treatment and extraction procedure. The primary target of pre treatment is to obtain the concentrated protein from smaller pieces of the fish viscera. In addition, their aim is to prepare homogeneous water and chopped viscera mixtures with the lowest fat percentage possible and other undesirable components for subsequent hydrolysis (He et al., $2013)^{[18,19]}$. In order to produce a solvent (acid or alkali) or enzymatic hydrolysis, water, chemicals or enzymes are added to the minced raw material. There is a need to interrupt the hydrolysis process by chemical or thermal treatment according to the hydrolysis procedure after a certain time when a certain desirable degree of hydrolysis is reached (Petrova et al., 2018) ${ }^{[33]}$. In order to extract the attached fats from the fish tissues, heat treatment, the use of solvents and pressing methods have been commonly used. Heat treatment is generally known among all techniques because it satisfies both the purposes of fat reduction and inactivation of the enzyme (Guérard et al., 2001) ${ }^{[16,17]}$. After heat treatment the solid residue is separated by using centrifugation technique. Similarly, (Valenzuela et al., 2001) has successfully used pressing technique coupled with heat treatment to get the solid mass followed by drying to obtain the moisture content less than 10 percentage (Valenzuela et al., 2001) alcohols such as ethanol, isopropyl alcohol, are also commonly used for the defatting in which fish minced are mixed with alcohols under continuous stirring for a fixed period of time (Dong et al., 2008) ${ }^{[11]}$. This approach is useful for minimizing the decay of bacteria as well as removing the fishy odor and bitter flavors (Hoyle et al., 1994) ${ }^{[20]}$. A modern technology has been used in some experiments to extract proteins from fish tissues. In addition to centrifugation and filtration, it consists of the solubilization of protein in acids or alkaline solutions to extract insoluble compounds; once separated; the proteins are precipitated by changing the $\mathrm{pH}$ to the isoelectric point and collected by centrifugation or decantation (Nolsøe et al., 2009) ${ }^{[31]}$.

\subsection{Hydrolysis of pretreated material}

Three different methods can be used to prepare protein hydrolysates from fish processing discards, namely the acid hydrolysis, alkali hydrolysis, and enzymatic process. Below is the underlying process, effects of multiple variables and advantages and drawbacks of each technique.To extract free amino acids and low molecular weight peptides, protein hydrolysis carried out for cleavage of peptide bonds by absorbing a molecule of water for each broken bond. In aquaculture and fisheries, the hydrolysis mechanism (chemical or biochemical) has recently been used to produce more appropriate and viable goods (Pasupuleti et al., 2008) [32].

\subsubsection{Acid hydrolysis}

It is a low-cost, easy and simple process that makes it important at the industrial level. The complete fish protein hydrolysis using hydrochloric acid or, in some cases, sulfuric acid has been performed at elevated temperatures and also at high pressures. The solution is neutralised to $\mathrm{pH} 6.0$ to 7.0 after hydrolysis, condensed and dried further. Absolute fish protein substrate hydrolysis can be accomplished in 18 hours at $118{ }^{\circ} \mathrm{C}$ in $6 \mathrm{M} \mathrm{HCl}$. Due to the low cost of processing and the consequent widespread hydrolysis, this method is often 
used to turn underused and secondary raw material from fish into fertilizer (Elavarasan et al., 2019) ${ }^{[12]}$. However during acid hydrolysis, important amino acids, such as tryptophan, methionine, cystine, are normally lost. In addition, asparagine and glutamine are converted into aspartic acid and, respectively, glutamic acid. In addition, owing to the formation of salts during the neutralization process, acquired hydrolysates have weak functional properties. Therefore, many methods of separation have been suggested, such as nano filtration and the use of ion exchange resins, with excellent performance (Pasupuleti et al., 2008) ${ }^{[32]}$.

\subsubsection{Alkaline hydrolysis}

Wide water-soluble polypeptides are easily broken and further reduced at a slower pace into basic compounds in the alkaline hydrolysis phase of fish protein. Sodium hydroxide is mainly used in the alkali hydrolysis process. A high $\mathrm{pH}$ of 12.5 at 95 ${ }^{\circ} \mathrm{C}$ for 20 minutes was used in the small-scale batch system developed to hydrolyze the fish protein concentrates to increase functionality (Elavarasan et al., 2019) ${ }^{[12]}$. The key drawback of this process is the development of low amino acid content hydrolysates such as cystine, lysine, arginine, serine, threonine, isoleucine and residues such as lanthionine and lysinoalanine (Tavano et al., 2013) ${ }^{[36]}$.

\subsubsection{Enzymatic hydrolysis}

In peptide bond cleavage, enzymatic hydrolysis uses mild conditions and is easier to control and more accurate; in addition, there are no side effects or losses in nutritional value, and it is easier to recover protein and purify those peptides (Tavano et al., 2013) ${ }^{[36]}$. Enzymatic hydrolysis is typically done from one to several hours at mild conditions: marginally elevated temperatures (typically about $35-65{ }^{\circ} \mathrm{C}$ ) and a certain $\mathrm{pH}$ according to the optimal requirements of the enzymatic systems used: alkali (e.g. alkalase), neutral (e.g. papain, bromelain, alkalase, neutrase, flavourzyme) or acid (pepsin). Animal (pepsin), plant (papain,) bromelain) or of microbial origin (alcalase, flavourzyme, neutrase) are enzymes used for the production of FPH. It is understood that microbial enzymes have greater $\mathrm{pH}$ and temperature tolerance (He et al., 2013) ${ }^{[18,19]}$. It is also possible to produce protein hydrolysates by using proteases found in the digestive system of fish, such as pepsin, trypsin, chymotrypsin, collagenase and elastase (Vannabun et al., 2014) ${ }^{\text {[39] }}$. Due to many peptide bonds and their particular accessibility to enzymatic reactions, enzymatic hydrolysis of proteins is a complex operation. Enzyme specificity is not the only aspect that determines the final product's peptide profile and factors such as temperature and $\mathrm{pH}$ play an significant role. The temperature and $\mathrm{pH}$ may have a substantial influence on the kinetics of the enzyme reaction and their effect on each enzyme is different. Generally, when the enzyme is most active, there is an ideal balance of both $\mathrm{pH}$ and temperature. Enzymes are deactivated by temperature and $\mathrm{pH}$ extremes by denaturing them (Vázquez et al., 2004) [40]. Protein hydrolysates have been produced at autolysis temperatures ranging from $40-50{ }^{0} \mathrm{C} \mathrm{C}$ and from the heads and viscera of sardinella Sardinellaaurita at $\mathrm{pH} \mathrm{8,} \mathrm{which} \mathrm{showed} \mathrm{that} \mathrm{adding} \mathrm{an} \mathrm{additional} \mathrm{enzyme} \mathrm{will}$ speed up the response and increase the degree of hydrolysis (Bougatef et al., 2008) ${ }^{[6]}$. In spite of the above advantages, when enzymatic hydrolysis is used, there are some drawbacks. High prices of industrial enzymes, poor yields, the need for special care to deactivate enzymatic hydrolysis, the complexities of process management in achieving a certain molecular mass of the protein degradation products and the bitterness of the final FPH are among them (He et al., 2013) $[18,19]$.

\subsection{Recovery of FPH}

Depending on the final application of the hydrolysates, FPH can be recovered or purified by different processes including centrifugation, nano-filtration, ultrafiltration, microfiltration, and ion exchange chromatography. The most used of the above was centrifugation, from which four stages are obtained: oil fraction, emulsion sheet, FPH and sludge

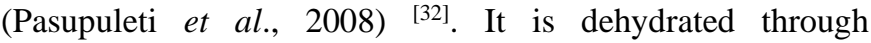
lyophilization or spraydrying after separating FPH by decantation to increase shelf life and provide greater ease of handling, transportation and storage. A creamy white powder with enhanced functional and bioactive properties is usually the final product and it should be stored below $0^{\circ} \mathrm{C}$ to enhance the stability of the product (He et al., 2013) ${ }^{[18,19]}$.

\section{Characterisation of FPH}

The purified FPH is subjected to various characterization techniques in order to confirm the molecular nature and other characteristics of the FPH. The characterization of FPH is generally done for the estimation of protein content using Lowry's method, molecular weight determination using polyacrylamide gel electrophoresis (SDS PAGE), protein structure using circular dichroism, detection of protease activity by Zymography, molecular mass detection by using orbitrap high resolution liquid chromatography mass spectrometry (O-HRLCMS), enzyme kinetic study using Lineweaver-Burk double reciprocal plot, detection of functional groups using infra red spectrophotometry and crystalline or amorphous nature of FPH can be determined by using X -ray powder diffraction study (Charu et al.,2020; Geethanjali et al., 2013; Kameshwar et al., 2014; Mohanty, 2020) $[9,14,22,27]$.

\section{Applications of Fish Visceral Hydrolysate}

Fish protein hydrolysate (FPH) is fish oil containing a combination of amino acids and peptides of varying molecular sizes. In the food, cosmetics, pharmacy, nutriceuticals and practical food markets, FPH finds use. The Indian marine food industry provides a large amount of protein-rich waste that can be efficiently processed into fish protein hydrolysate by an optimized approach to the higher return of the seafood processor. In this section we will discuss various applications of FPH in detail.

\subsection{FPH as potential source of microbial growth media} FPH obtained from Catla (Catla catla), Rohu (Labeo rohita), tuna and other species of fishes were found excellent growth promoters for various species of bacterias, yeasts and molds due to high content of peptones, amino acids and other essential ingredients (Guérard et al., 2001) ${ }^{[16,17]}$. As a growth vector for various species of microorganisms (pseudomonas, vibrio and squid), fish viscera peptones from tuna, yellow stripe, swordfish, rainbow trout and squid were also analyzed which, because of their pathogenic or probiotic properties, are of concern to aquaculture (Vázquez et al., 2004; Husin et al., 2015) ${ }^{[40,21]}$ studied comparison of microbial growth on fish waste peptones from different hydrolysis methods. For peptone recovery, their research used mixtures of sardine and mackerel fish wastes. As nitrogen supplies for microbial growth, recovered peptones from various hydrolysis methods 
(alkaline and enzymatic) were supplied. The efficiency of Peptone in microbial production was found to be impaired by the process of hydrolysis. Development of Saccharomyces cerevisiae using enzymatic peptone (Alcalase enzyme) was superior compared to development using other peptone forms. For Bacillus subtilis growth, the same pattern was observed. The method of hydrolysis played an important role in the development of peptone with a high protein content and degree of hydrolysis, which led to better microbial growth efficiency of the fish waste peptone. In conclusion, peptones derived from a sardine and mackerel waste mixture are theoretically viable to replace current commercial peptones as a microbial culture medium (Husin et al., 2015) ${ }^{[21]}$. Different peptones obtained from hydrolysed visceral homogenates of Bolti fish (Tilapia nilotica) residues demonstrated their suitability to promote the growth of lactic acid bacteria (mainly Lactobacillus sake Lb 706). The findings showed that the Bolti fish hydrolysate provided impressive results in expensive commercial media, explicitly recommended for the cultivation and large-scale development of lactic acid bacteria (Deraz et al., 2011) ${ }^{[10]}$. FPH derived from cod stomachs demonstrated better efficiency for the development of pathogens such as Vibrio anguilarum and Aeromonas salmonicida than commercial products. (Gildberg et al., 2010) ${ }^{[15]}$. As a combined source of nitrogen, amino acids and vitamins in microbial growth media, three hydrolysate produced from cod viscera by various enzymatic hydrolysis procedures have been tested against Escherichia coli, Bacillus subtilis, Lactobacillus sakei, Saccharomyces cerevisiae and Aspergillus niger, the performance of these viscera hydrolysate was compared to the performance of typical commercial peptones. The findings suggest those fish hydrolysates are generally attractive alternatives to other forms of commercial nitrogen currently available (Aspmo et al., 2005) ${ }^{[2]}$. As growth media for the bacterial strains of Pseudomonas putida, Pseudomonas aeruginosa, Streptococcus faecium, Listeria monocytogenes, Bacillus subtilis, Bacillus licheniformis and Micrococcus lysodeikticus, tuna head hydrolysate, using the industrial enzymes Alcalase ( ) (Alc) and ProtamexTM (Prot), have been studied as an alternative to widely available complex sources (peptones and/or extracts) (Safari et al., 2012) ${ }^{[34]}$. These evidences clearly demonstrated the potential use of FPH as microbial growth promoter including both gram positive and negative bacterias. The type of hydrolysis, enzyme used and other conditions like temperature, $\mathrm{pH}$ are important factors to be considered during extraction of FPH and that governs the suitability and usefulness of FPH as microbial growth promoter. The extensive research work is still needed in this area.

\subsection{FPH as nutritional supplement}

FPH produced from the proteins of fish are excellent nutritional supplements can be easily used as bioactive compounds and absorbed and used for diverse metabolic operations. FPH can be used in multiple foods as usable additives because they have many major and special properties, such as water holding ability, oil absorbing capability, protein solubility, gelling activity, foaming ability and emulsification capability (Chalamaiah et al., 2010) ${ }^{[8]}$. In different hydrolysis conditions, the amino acid composition of FPH from different raw materials generated using different enzyme sources is predicted to vary. In general, the essential amino acids needed are abundant in FPH, with a rich content of glutamic and aspartic acid. FPH has non-essential amino acids, too. The presence of aromatic amino acids in hydrolysates of fish frame protein has been confirmed. Studies have clearly demonstrated that an optimal supply of important amino acids may be FPH from fish meat / fish waste (Elavarasan et al., 2019) ${ }^{[12]}$. The use FPH have been already explored in various food products including rice, snacks, fish and meat products, crackers and cereals but very limited number of clinical trials have been performed on FPH (Marchbank et al., 2008) ${ }^{[26]}$. The following table represents the approximate composition of some of the nutritional components present in FPH (Marchbank et al., 2008) ${ }^{[26] .}$

Table 2: Nutritional components of FPH and approximate quantity of thereof

\begin{tabular}{|c|c|c|}
\hline Sr. No & Nutritional component & \% present \\
\hline 1 & Protein & $60-90$ \\
\hline 2 & Moisture & Less than $10 \%$ \\
\hline 3 & Fat & Less than $5 \%$ \\
\hline 4 & Ash & 0.45 o $27 \%$ \\
\hline
\end{tabular}

\subsection{FPH as bioactive agent}

The potential of hydrolysates as antioxidants, antihypertensives and antimicrobials from several sources of fish protein has been studied. A peptide with high antioxidant properties was isolated from Megalaspis cordyla, a horse mackerel viscera protein. To extract possible protein hydrolysate, in vitro gastrointestinal digestion was used and subjected to sequential chromatographic methods utilizing quick protein solvent. The extracted protein had shown greater antioxidant property than natural alpha tocopherol in protection of polyunsaturated fatty acid (PUFA) (Kumar et al., 2011) ${ }^{[24]}$. Similarly, FPH derived from sardinella Sardinella aurita heads and viscera showed excellent scavenging effect on free radical DPPH and inhibition of linoleic acid. The findings of autoxidation show that the above peptides demonstrated more than 50 percent linoleic acid peroxidation inhibition and roughly 41 percent antioxidant function (Kumar et al., 2011) [24]. Five commercially available proteases, including alkali protease, papain, neutral protease, pepsin, and trypsin, were hydrolyzed with Pacific abalone (Haliotis discus hannailno) viscera, which are usually discarded as by-products. The hydrolysates obtained were fractionated using the bioreactor method of the ultrafiltration membrane. The resulting hydrolysate fractions, including the scavenging effect on the 1,1-diphenyl-2picrylhydrazyl (DPPH) radical, the scavenging effect on the hydroxyl radical, and the decreasing strength, were investigated for their antioxidant activities. The findings revealed that the hydrolysate fractions were efficient antioxidants and that the hydrolysates' antioxidant activity was related to the form of enzyme used. The abalone viscera may be used as a by-product as a possible source of antioxidant peptides (Zhou et al., 2012) ${ }^{[43]}$. Hydrolysates of the fish viscera protein obtained from Parastromateus niger have a protective effect on DNA against hydroxyl radical damage. The existence of antioxidant peptides in hydrolysates derived from fish co-products indicates both these findings (Nazeer et al., 2011) ${ }^{[29]}$. It has been well known that FPH peptides are rich source of arginine, valine, and leucine and other types of amino acids. Reports indicate higher antihypertensive behavior in peptides with low molecular weight $(<1 \mathrm{kDa})$ and shorter chain length ( $<20$ amino acids). Because these peptides have shown the inhibitory function of 
Angiotensin Converting Enzyme in vitro and in vivo, their ability to be used as antihypertensive drugs is outrageous. However, to provide an improved understanding of the interaction of peptides with the enzyme, the new emphasis on study in the field of molecular docking is important (Benjakul et al., 2014) ${ }^{[4,39]}$. Angiotensin converting enzyme inhibitory characteristics of visceral hydrolysate proteins and peptides have been identified with $\left(\mathrm{IC}_{50}\right.$ value $75 \mu \mathrm{g} / \mathrm{ml}$ ) and sardinella $\left(\mathrm{IC}_{50}\right.$ value $0.8-1.2 \mathrm{mg} / \mathrm{ml}$ ), ribbon fish backbones $\left(\mathrm{IC}_{50}\right.$ value $\left.5.6 \mu \mathrm{M}\right)$ and yellow fin sole $\left(\mathrm{IC}_{50}\right.$ value $28.7 \mu \mathrm{g} /$ $\mathrm{ml}$ ), salmon heads, flathead, silver storage and barramundi (Abdelhedi et al., 2016) "1]. The angiotensin converting enzyme inhibitory (ACEI) activities of protein hydrolysates prepared from sardinella heads and viscera (Sardinella aurita) by treatment with separate proteases have also been investigated. The ACE inhibitory IC50 values for sardinelle protein hydrolysate by-products and fraction $\mathrm{P} 4$ were $1.2 \pm$ 0.09 and $0.81 \pm 0.013 \mathrm{mg} / \mathrm{ml}$, respectively (Bougatef et al., 2008) ${ }^{[6]}$. Hydrolysis of the by-product proteins of cuttlefish with B alkaline proteases resulted in to the substance with excellent solubility over a wide $\mathrm{pH}$ spectrum and high ACE- inhibitory activity resulted from licheniformis. This research indicates that FPH may be used for the production of functional foods for hypertension prevention (Balti et al., 2010) ${ }^{[3]}$. Antimicrobial peptides are chains of amino acids that are less than $10 \mathrm{kDa}$ by molecular weight and typically contain less than 50 amino acids, about all of which are hydrophobic. Against different Gram-negative and Grampositive strains, nearly all antimicrobial peptides from fish have antibacterial behaviors. These antimicrobial peptides are possible candidates for modern medicinal antibiotic production as well as food industry antimicrobial agents. These antimicrobial peptides can also be used as antibacterial, antiviral, antimicrobial, immunomodulatory, and antitumor agents (Najafian et al., 2012) ${ }^{[28]}$.

\subsection{FPH as nutriceuticals}

FPH has greater antioxidant, anti-obesity, anticancer, anticoagulant, immunomodulatory and antihypertensive activity so widely used in nutriceuticals. Table 3 describes the various commercial nutriceuticals products of FPH used in various countries.

Table 3: Commercial nutriceuticals products of FPH marketed in different countries (Elavarasan et al., 2019) ${ }^{[12]}$

\begin{tabular}{|c|c|c|c|c|}
\hline Sr. No & Product & Details & Application \\
\hline 1 & Vasotensin & $\begin{array}{c}\text { Bonito (Sardaorientalis) } \\
\text { by thermolysin hydrolysis }\end{array}$ & maintenance of blood pressure \\
\hline 2 & Amizate & $\begin{array}{c}\text { Atlantic salmon fish } \\
\text { proteins by autolysis }\end{array}$ & Sport nutritional product \\
\hline 3 & Protizen & $\begin{array}{c}\text { enzymatic hydrolysis } \\
\text { ofwhite fish proteins }\end{array}$ & Dietary supplement to fight against stress and \\
\hline 4 & Seacure & $\begin{array}{c}\text { Hydrolysis of deep } \\
\text { oceanwhite fish proteins } \\
\text { North Atlantic fish } \\
\text { Molvamolva by } \\
\text { enzymatic hydrolysis }\end{array}$ & $\begin{array}{c}\text { Supports the cells of GIT } \\
\text { Andhelps in functioning of Bowel }\end{array}$ & $\begin{array}{c}\text { For cholesterol regulation, } \\
\text { stress control, for cardiac } \\
\text { benefit }\end{array}$ \\
\hline
\end{tabular}

\section{Conclusion}

FPH offers many valuable characteristics, making it desirable for its applicability in various sectors including agriculture, pharmaceuticals, biotechnology, food processing. The functionality, bioactivity, and nutritional benefits of FPH extend its scope of use. The physicochemical, functional and bioactive characteristics of the FPH and, subsequently, its use as a food component are prodigiously affected by the option of method used in the process of hydrolysis. Although considerable research has made strides, more more needs to be achieved. Considering the physicochemical difficulties associated with FPH, its excellent nutritional and functional properties generate possibilities for its usage in both the food and health industries.

\section{References}

1. Abdelhedi O, Jridi M, Jemil I, Mora L, Toldrá F, Aristoy MC et al. Combined biocatalytic conversion of smooth hound viscera: Protein hydrolysates elaboration and assessment of their antioxidant, anti-ACE and antibacterial activities. Food Res Int. 2016;86:9-23.

2. Aspmo SI, Horn SJ, Eijsink VG. Hydrolysates from Atlantic cod (Gadus morhua L.) viscera as components of microbial growth media. Process Biochemistry 2005;40:3714-3722.

3. Balti R, Bougatef A, El-Hadj Ali N, Zekri D, Barkia A, Nasri M. Influence of degree of hydrolysis on functional properties and angiotensin I-converting enzyme-inhibitory activity of protein hydrolysates from cuttlefish (Sepia officinalis) by-products. J Sci Food Agri 2010;90:2006-2014.
4. Benjakul S, Yarnpakdee S, Senphan T, Halldorsdottir SM, Kristinsson HG. Fish protein hydrolysates: production, bioactivities and applications. Antioxidants and functional components in aquatic foods, 1 st ed. Reykjavik, Iceland: Matil Ltd. 237Á83 2014.

5. Bhaskar N, Sachindra NM, Suresh PV, Mahendrakar NS. Microbial reclamation of fish industry by-products. Aquaculture microbiology and biotechnology. Science Publishers, Enfield, New Hampshire 2011, 249-276.

6. Bougatef A, Nedjar-Arroume N, Ravallec-Plé R, Leroy $\mathrm{Y}$, Guillochon D, Barkia A, et al. Angiotensin Iconverting enzyme (ACE) inhibitory activities of sardinelle (Sardinella aurita) by-products protein hydrolysates obtained by treatment with microbial and visceral fish serine proteases. Food chem 2008;111:350356.

7. Chalamaiah M, Hemalatha R, Jyothirmayi T. Fish protein hydrolysates: proximate composition, amino acid composition, antioxidant activities and applications: a review. Food chem 2012;135:3020-3038.

8. Chalamaiah M, Rao GN, Rao DG, Jyothirmayi T. Protein hydrolysates from meriga (Cirrhinus mrigala) egg and evaluation of their functional properties. Food Chem 2010;120:652-657.

9. Charu B, Ragini G. Optimization and characterization of trypsin of Labeo rohita from its visceral waste. GSC Advanced Research and Reviews 2020;3:039-047.

10. Deraz SF, El-Fawal GF, Abd-Ellatif SA, Khalil AA. Autohydrolysed Tilapia nilotica fish viscera as a peptone source in bacteriocin production. Indian J. 
Microbiol 2011;51:171-175.

11. Dong S, Zeng M, Wang D, Liu Z, Zhao Y, Yang H, Antioxidant and biochemical properties of protein hydrolysates prepared from Silver carp (Hypophthalmichthys molitrix). Food chem. 2008;107:1485-1493.

12. Elavarasan K. Health Benefits and Potential Applications of Fish Protein Hydrolysate. ICAR-Central Institute of Fisheries Technology 2019.

13. Freitas-Júnior AC, Costa HM, Icimoto MY, Hirata IY, Marcondes M, Carvalho Jr LB et al. Giant Amazonian fish pirarucu (Arapaima gigas): Its viscera as a source of thermostable trypsin. Food chem. 2012;133:1596-1602.

14. Geethanjali S, Subash A. Comparative study on precipitation techniques for protease isolation and purification from Labeo rohita Viscera. J. Aquat. Food Prod. Technol 2013;22:121-128.

15. Gildberg A, Dahl R, Mikkelsen H, Nilsen K. Peptones from Atlantic cod Stomach as nitrogen sources in growth media to marine bacteria. J Aquat. Food Prod. Technol 2010;19:75-83.

16. Guérard F, Dufosse L, De La Broise D, Binet A. Enzymatic hydrolysis of proteins from yellowfin tuna (Thunnus albacares) wastes using Alcalase. J Mol. Catal., B Enzym 2001;11:1051-1059.

17. Guérard F, Dufosse L, De La Broise D, Binet A. Enzymatic hydrolysis of proteins from yellowfin tuna (Thunnus albacares) wastes using Alcalase. J Mol. Catal., B Enzym 2001;11:1051-1059.

18. He S, Franco C, Zhang W. Functions, applications and production of protein hydrolysates from fish processing co-products (FPCP). Food Res. Int. 2013;50:289-297.

19. He S, Franco C, Zhang W. Functions, applications and production of protein hydrolysates from fish processing co-products (FPCP). Food Res. Intern 2013;50:289-297.

20. Hoyle NT, Merrltt JH. Quality of fish protein hydrolysates from herring (Clupea harengus). J. food Sci. 1994;59:76-79.

21. Husin N, Mustapa KSM, Chuan LT, Muhammad NF, Jusoh N. Comparison of microbial growth on fish waste peptones from different hydrolysis methods. In International Conference on Biomedical Engineering and Technology 2015;81:54-57.

22. Kameshwar S, YV, Boora N, Tyagi P. Isolation, purification and characterization of secondary structure and kinetic study of lipase from Indian major Carp, Catla catla (Catla). Enz. Eng. 2014;3:1-8

23. Kristinsson HG, Rasco BA. Biochemical and functional properties of Atlantic salmon (Salmo salar) muscle proteins hydrolyzed with various alkaline proteases. J. Agric. Food Chem 2000;48:657-666.

24. Kumar NS, Nazeer RA, Jaiganesh R. Purification and biochemical characterization of antioxidant peptide from horse mackerel (Megalaspis cordyla) viscera protein. Peptides 2011;32:1496-501.

25. Lauria V, Das I, Hazra S, Cazcarro I, Arto I, Kay S, et al Importance of fisheries for food security across three climate change vulnerable deltas. Sci Total Environ. 2018;640:1566-1577.

26. Marchbank T, Limdi JK, Mahmood A, Elia G, Playford RJ. Clinical trial: protective effect of a commercial fish protein hydrolysate against indomethacin (NSAID)-induced small intestinal injury. Aliment. Pharmacol. Ther 2008;28:799-804.
27. Mohanty B. Purification and characterization of trypsin from the visceral wastes of grass carp Ctenopharyngodon idella (Valenciennes, 1844). J Entomol. Zool. 2020;8:573-579.

28. Najafian L, Babji AS. A review of fish-derived antioxidant and antimicrobial peptides: their production, assessment, and applications. Peptides 2012;33:178-185.

29. Nazeer RA, Kumar NS. Purification and identification of antioxidant peptide from black pomfret, Parastromateus niger (Bloch, 1975) viscera protein hydrolysate. Food Sci. Biotech 2011;20:1087.

30. New MB. History and global status of freshwater prawn farming. Freshwater prawn culture: the farming of Macrobrachium rosenbergii. Blackwell Science, Oxford. 2000, 1-11.

31. Nolsøe H, Undeland I. The acid and alkaline solubilization process for the isolation of muscle proteins: state of the art. Food Bioproc. Tech 2009;2:1-27.

32. Pasupuleti VK, Braun S. State of the art manufacturing of protein hydrolysates. In Protein hydrolysates in biotechnology Springer, Dordrecht 2008, 11-32.

33. Petrova I, Tolstorebrov I, Eikevik TM. Production of fish protein hydrolysates step by step: technological aspects, equipment used, major energy costs and methods of their minimizing. Int Aquat Res 2018;10:223-241.

34. Safari R, Motamedzadegan A, Ovissipour M, Regenstein JM, Gildberg A, Rasco B. Use of hydrolysates from yellowfin tuna (Thunnus albacares) heads as a complex nitrogen source for lactic acid bacteria. Food Bioproc Technol 2012;5:73-79.

35. Silva JFX, Ribeiro K, Silva JF, Cahú TB, Bezerra RS. Utilization of tilapia processing waste for the production of fish protein hydrolysate. Anim. Feed Sci Technol 2014;196:96-106.

36. Tavano OL. Protein hydrolysis using proteases: An important tool for food biotechnology. J Mol. Catal., B Enzym 2013;90:1-11.

37. Thiansilakul Y, Benjakul S, Shahidi F. Antioxidative activity of protein hydrolysate from round scad muscle using alcalase and flavourzyme. J Food Biochem 2007;31:266-287.

38. Valenzuela A, Sanhueza J, de la Barra F. El aceite de pescado: ayer un desecho industrial, hoy un producto de alto valor nutricional. Revistachilena de nutrición 2012;39:201-209.

39. Vannabun A, Ketnawa S, Phongthai S, Benjakul S, Rawdkuen S. Characterization of acid and alkaline proteases from viscera of farmed giant catfish. Food Biosci 2014;6:9-16.

40. Vázquez JA, González MP, Murado MA. A new marine medium: Use of different fish peptones and comparative study of the growth of selected species of marine bacteria. Enzyme Microb. Technol 2004;35:385-392.

41. Vidotti RM, Viegas EMM, Carneiro DJ. Amino acid composition of processed fish silage using different raw materials. Anim. Feed Sci Technol 2003;105:199-204.

42. Villamil O, Váquiro H, Solanilla JF. Fish viscera protein hydrolysates: Production, potential applications and functional and bioactive properties. Food Chem 2017;224:160-171.

43. Zhou DY, Zhu BW, Qiao L, Wu HT, Li DM, Yang JF et al. In vitro antioxidant activity of enzymatic hydrolysates prepared from abalone (Haliotis discus hannailno) viscera. Food Bioprod Proc 2012;90:148-154. 